CASSOWARY volume 4 (1): 19-27

ISSN : 2614-8900

E-ISSN : 2622-6545

Program Pascasarjana Universitas Papua, https://pasca.unipa.ac.id/

\title{
Kondisi Biofisik Serta Gangguan Terhadap Hutan Pada Areal Buffer Zone Bantaran Sungai Apo Distrik Jayapura Utara
}

\author{
Valentin Paisei, Soetjipto Moeldjono, Rima H Siburian* \\ Program Studi S2 Kehutanan, Program Pascasarjana, Universitas Papua \\ Jalan Gunung Salju, Amban, Manokwari, Kodepos 98314, Papua Barat, Indonesia. \\ *Email: r.siburian@unipa.ac.id
}

\begin{abstract}
APO river has a length of 3 kilometers with a width of 7 meters and flows from headwaters in the village Angkasa Pura to empty into the sea which is administered into the village administration area Bhayangkara. The purpose of this study to (1) identify the biophysical conditions in the area of the buffer zone of the river sepantaran Apo. (2) Identifying the form of land use in the bufferzone area of the Apo River from downstream to upstream. (3) Provide management recommendations in the form of land suitability directions to carry out Forest and Land Rehabilitation activities in the bufferzone area of the Apo river. Descriptive method with map interpretation and consists of several stages that include the preparation stage, the stage of processing and preliminary processing of data, field checking stage, the stage of data analysis, and recommendations on the implementation of Forest and Land Rehabilitation activities in the area of the river BufferZone Apo. Biophysical conditions of the area BufferZone river Apo has the characteristics of land cover types that include dry forest primary dry forest secondary, dryland farming mixed with shrubs, bushes, settlements, soil types litosol, with altitude ranging from $0 \mathrm{~m}$ asl - 690m above sea level. BufferZone slope in the area of very varied ranging from flat to very steep.In accordance with the decline in the quality of primary dryland forest to secondary dryland forest covering 22.04 hectares in 2009-2018 and activities that resulted in the removal of 44.80 hectares of secondary forest in 2000-2009, the large changes in the nature of both deforestation and degradation of from 2000 to 2018 thus covering an area of 66.84 hectares or $18.94 \%$ of the total research area, namely the Apo river bufferzone. Most of the areas that are categorized as quite suitable are forest areas that are experiencing deforestation and degradation and the recommended land is suitable enough to carry out RHL activities in the bufferzone area of the Apo River, only covering an area of 91.05 hectares or $25.80 \%$ of the bufferzone area. Apo river.
\end{abstract}

Keywords: biophysical conditions, change in land cover, recommendations for land and forest rehabilitation, APO river, Jayapura City.

\section{PENDAHULUAN}

Hutan mempunyai tiga fungsi pokok yaitu fungsi lindung, fungsi konservasi, dan fungsi produksi (Undang-undang nomor 41 tahun 1999). Sebagai sumber kehidupan hutan memberikan manfaat secra ekonomi, sosial budaya dan manfaat ekologi. Hutan berperan penting dalam mengkonservasi daerah aliran sungai (DAS) karena hutan mempunyai sifat meredam tingginya debit sungai 
pada musim hujan dan berpotensi memelihara kestabilan air sungai di musim kemarau (Wibowo et al 2020; Tanati et al, 2020). Kota Jayapura merupakan Ibu Kota dari Provinsi paling timur di Indonesia yaitu Provinsi Papua, secara geografis Kota Jayapura terletak pada $1^{\circ} 28^{\prime} 17,26^{\prime \prime}-3^{\circ} 58^{\prime} 0,82^{\prime \prime}$ Lintang Selatan dan $137^{\circ} 34^{\prime} 10,6^{\prime \prime}-141^{\circ} 0$ '8,22" Bujur Timur dengan batas-batas geografis sebelah timur berbatasan dengan Negara $\mathrm{Pa}-$ pua New Guenea, sebelah barat berbatasan dengan Kabupaten Jayapura, sebelah selatan berbatasan dengan Kabupaten Kerom dan sebelah utara berbatasan dengan Samudera Pasifik. Secara administrasi kota jayapura terdiri dari 5 Distrik yaitu Jayapura Utara, Jayapura Selatan, Distrik Abe-pura, Distrik Muara Tami, dan Distrik Heram sedangkan untuk kondisi Geohidrologi Kota Jayapura memiliki 17 sungai kecil yang mana $15 \mathrm{di}$ antaranya bermuara ke laut, dan 2 diantaranya bermuara di Danau Sentani (Profil Kota Jayapura, 2016-2020). Sungai APO merupakan salah satu dari 17 sungai yang terdapat di Kota Jayapura dan juga merupakan salah satu penyuplai air untuk penduduk Distrik Jayapura utara selain sungai Anafre, sungai Kloofkamp, su-ngai Bahabuaya, Sungai Dok IV dan sungai Dok VII yang juga mengalir di Distrik Jayapura Utara. Sungai APO memiliki panjang 3 kilo meter dengan lebar 7 meter dan mengalir dari daerah hulu di kelurahan Angkasa Pura sampai bermuara di laut yang secara administrasi masuk ke dalam daerah administrasi kelurahan Bhayangkara. Guna penyusunan rencana pengendalian terhadap gangguan dan kerusakan lingkungan di sepanjang areal yang dilalui oleh aliran sungai Apo, maka perlu diadakan identifikasi tentang: (1) Kondisi biofisik kawasan di dalam areal buffer zone sepantaran sungai Apo, (2) mengidentifikasi bentuk penggunaan lahan di dalam areal bufferzone sungai Apo mulai dari hilir sampai ke hulu, (3) Skoring kelayakan areal untuk dilakukan langkah rehabilitasi guna mengembalikan fungsi hutan yakni sebagai pengatur tata air untuk daerah sekitarnya. serta meminimalisasikan sedimentasi yang diakibatkan aliran permukaan pada areal yang terbuka yang kemudian masuk ke aliran sungai primer, yang dapat berdampak banjir dan longsor pada daerah hilir.

\section{MATERI DAN METODE}

Penelitian ini berlangsung sela-ma 3 minggu pada bulan Desember 2020 pada areal buffer zone 500 meter sungai Apo yang mengalir dari wilayah Kelurahan Angkasa pura sampai bermuara pada wilayah Kelurahan Bhayangkara di Distrik Jayapura Utara. Alat yang digunakan dalam penelitian ini meliputi: Software ArcGIS 10.4, Unit PC dengan Spec yang memenuhi syarat untuk pemetaan, GPS (Global Positioning System), Kamera Digital, Meter roll, Alat tulis menulis dan papan lapangan. Bahan yang digunakan adalah data spasial peta tematik yang meliputi : Peta administrasi Kota Jayapura yang bersumber dari BIG tahun 2016,Peta tutupan lahan Kementerian Kehutanan tahun 2000, 2009, dan 2018, Peta jalur aliran sungai Apo mulai (hasil digitasi citra dan tracking langsung mengikuti jalur sungai di lapangan), Peta jenis tanah provinsi Papua yang bersumber dari PUSLITANAK tahun 2012,Peta curah hujan yang bersumber dari BAPPEDA tahun 2008, Peta kontur dan kelerengan yang bersumber dari SRTM tahun 2008, Peta Fungsi Kawasan Hutan yang bersumber dari SK Menhut no 782 Provinsi Papua tahun 2012, Peta lahan kritis yang bersumber dari KLHK tahun 2011,Citra satelit BING yang bersumber dari SAS Planet tahun 2012. Penelitian ini menggunakan metode deskriptif dengan teknik interpretasi peta. Prosedur terdiri dari be- 
berapa tahap yang mencakup tahap persiapan, tahap pengolahan dan pemprosesan awal data, tahap pengecekan lapang, tahap analisa data, dan rekomendasi pelaksanaan kegiatan Rehabilitasi Hutan dan Lahan pada areal bufferzone sungai Apo.Variabel dalam penelitian ini meliputi Kondisi biofisik (topografi, jenis tanah, tutupan lahan dan penggunaan lahan),Perubahan Tutupan Lahan (laju dan luasan deforestasi,laju dan luasan degradasi),Kesesuaian Lahan Untuk Penerapan Rehabilitasi Hutan dan Lahan (RHL). Data akan dianalisis secara spasial dan nonspasial, di mana analisis spasial diguna-kan untuk mendapatkan informasi keruangan kondisi biofisik, perubahan tutu-pan lahan serta kesesuaian lahan untuk melaksanakan kegiatan RHL sedangkan analisis nonspasial digunakan untuk memperoleh informasi yang bersifat kuantitatif seperti luasan dari masingmasing unsur biofisik, luasan perubahan tutupan lahan, dan juga luasan areal yang sesuai untuk dilakukan kegiatan rehabilitasi hutan dan lahan pada areal bufferzone sungai Apo secara tabulasi.

\section{HASIL DAN PEMBAHASAN}

\section{Gambaran Umum Lokasi Penelitian}

Kota Jayapura merupakan Ibu Kota Provinsi Papua, secara geografis Kota Jayapura terletak pada $1^{\circ} 28^{\prime} 17,26^{\prime \prime}$ 3 $58^{\prime} 0,82$ " Lintang Selatan dan $137^{\circ} 34^{\prime} 10,6^{\prime \prime}-141^{\circ} 0^{\prime} 8,22^{\prime \prime}$. Luasan Kota

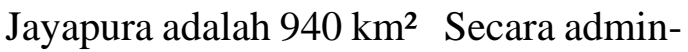
istrasi kota jayapura terdiri dari 5 Distrik yaitu Distrik Jayapura Utara, Distrik Jayapura Selatan, Distrik Abepura, Distrik Muara Tami, dan Distrik Heram, Lokasi penelitian adalah areal dalam radius 500 meter dari jalur sungai Apo yang terdapat di Distrik Jayapura Utara.

Lokasi penelitian berada pada radius 500 meter dari jalur sungai Apo yang terdapat di Distrik Jayapura Utara Secara geografis areal bufferzone sungai Apo terbentang antara $2^{\circ} 30^{\prime} 52,743^{\prime \prime} L S$. $140^{\circ} 41$ ' 26,297' $B T-2^{\circ} 32$ ' 31,057" LS. $140^{\circ} 42^{\prime}$ 25,036" $B T$ dan $2^{\circ} 31^{\prime}$ ' 15,889" LS. $140^{\circ} 41$ ' 26,955" BT $2^{\circ} 31$ ' 32,422” LS. $140^{\circ} 42^{\prime}$ 30,516 “ $B T$, dengan luas 352,89 dengan bagian hulu terdapat pada Kelurahan Angkasa dan bagian hilir masuk ke dalam daerah administrasi Kelurahan Bhayangkara. Sungai ini melewati pusat pemukiman terbesar di Kelurahan Bhayangkara yakni Apo sehingga disebut sebagai sungai Apo.

\section{Fungsi Kawasan}

Berdasarkan Surat Keputusan Mentri Kehutanan Nomor 782 Tahun 2012, maka lokasi penelitian terbagi menjadi dua areal kawasan yakni areal penggunaan lain (APL) dan Kawasan Suaka Alam yang secara detail ditunjuk sebagai kawasan Cagar Alam (CA) Cyclop yang membentang dari wilayah Kabupaten Jayapura sampai dengan Wilayah Kota Jayapura. Berikut Tabel pembagian status kawasan pada areal bufferzone sungai Apo.

Tabel 1. Luas kawasan Areal Bufferzone APO

\begin{tabular}{cccc}
\hline No & $\begin{array}{c}\text { Fungsi } \\
\text { Kawasan }\end{array}$ & $\begin{array}{c}\text { Luas } \\
(\mathbf{H a})\end{array}$ & $\begin{array}{c}\text { Persentase } \\
(\boldsymbol{\%})\end{array}$ \\
\hline $\mathbf{1}$ & APL & 112,26 & 31,81 \\
$\mathbf{2}$ & KSA & 240,63 & 68,19 \\
\hline & Total & 352,89 & 100 \\
\hline
\end{tabular}

Berdasarkan Tabel 1 terlihat bahwa status kawasan pada areal bufferzone sungai Apo Sebagian besar merupakan kawasan cagar alam cyclop yang berada pada wilayah administrasi Kota Jayapura. dari total areal seluas 352, 89 kawasan cagar alam di areal bufferzone sungai Apo adalah sebluas 240,63 atau $68,19 \%$ areal penelitian merupakan kawasan cagar alam. 


\section{Biofisik}

\section{Jenis Tanah}

Jenis tanah yang terdapat pada lokasi penelitian adalah tanah Litosol dengan luas keseluruhan 352,89 Ha.

Tabel 2. Tipe tanah pada kawasan bufferzone APO

\begin{tabular}{cccc}
\hline No & $\begin{array}{c}\text { Tipe } \\
\text { Tanah }\end{array}$ & Luas (ha) & $\begin{array}{c}\text { Persentase } \\
(\mathbf{\%})\end{array}$ \\
\hline 1 & Litosol & 352,89 & 100 \\
\hline
\end{tabular}

\section{Kelerengan}

Kelas kelerengan pada areal penelitian sangat bervariasi, mulai dari areal yang datar sampai ke sangat curam di mana areal dengan kelas lereng yang curam mendominasi dengan luasan sebesar 161,66 hektar atau sebesar 45,81\% dari total keseluruhan areal dan areal dengan kelas lereng yang masuk kategori datar memiliki luasan terkecil yaitu seluas 25,79 hektar atau sebesar 7,31\% dari total areal bufferzone sungai Apo
Tabel 3. Klasifikasi kelas lereng areal bufferzone APO

\begin{tabular}{|c|c|c|c|}
\hline No & $\begin{array}{l}\text { Klasifikasi } \\
\text { Kelas } \\
\text { Lereng }\end{array}$ & $\begin{array}{l}\text { Luas } \\
\text { (Ha) }\end{array}$ & $\begin{array}{l}\text { Persen- } \\
\text { tase }(\%)\end{array}$ \\
\hline 1 & Datar & 25,79 & 7,31 \\
\hline 2 & Landai & 48,76 & 13,82 \\
\hline 3 & $\begin{array}{l}\text { Agak } \\
\text { Curam }\end{array}$ & 71,34 & 20,22 \\
\hline 4 & Curam & 161,66 & 45,81 \\
\hline 5 & $\begin{array}{l}\text { Sangat } \\
\text { Curam }\end{array}$ & 45,32 & 12,84 \\
\hline Tota & & 353,89 & 100 \\
\hline
\end{tabular}

\section{Ketinggian Tempat}

Ketinggian lokasi penelitian yang meliputi sungai APO yang diukur dari hilir sampai dengan hulu berkisar antara ketinggian 0-690 $\mathrm{m}$ dpl sehingga menjadikan areal bufferzone sungai Apo masuk dalam kategori ketinggian rendah sampai ke sedang seperti disajikan pada Gambar 1.

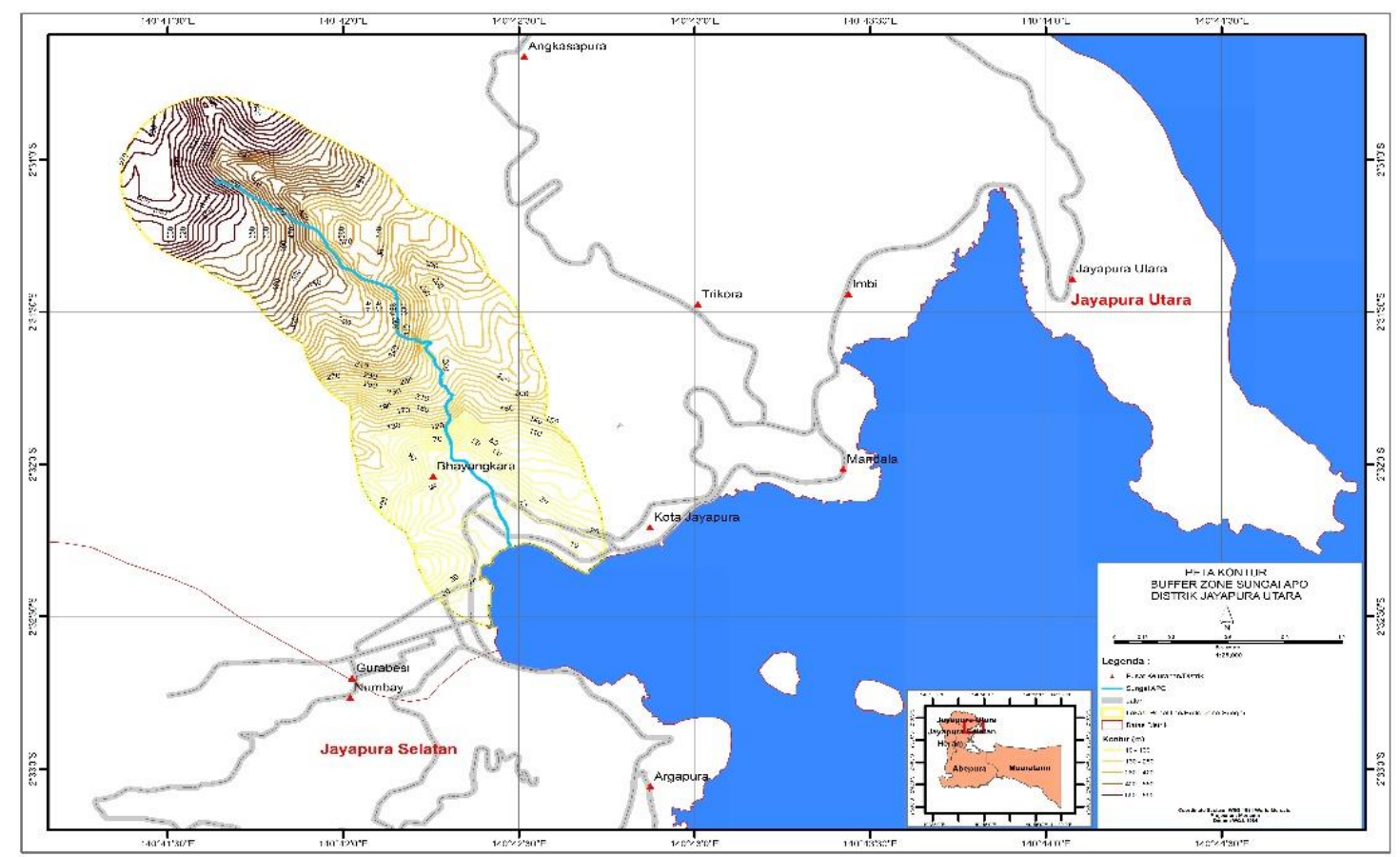

Gambar 1. Ketinggian tempat pada kawasan bufferzone APO 
Tabel 4. Kondisi tutupan lahan bufferzone APO

\begin{tabular}{clcc}
\hline No & \multicolumn{1}{c}{ Tipe Tutupan Lahan } & $\begin{array}{c}\text { Luas } \\
\text { (ha) }\end{array}$ & Persentase (\%) \\
\hline $\mathbf{1}$ & Hutan Lahan Kering Primer & 124,52 & 35,29 \\
$\mathbf{2}$ & Hutan Lahan Kering Sekunder & 22,04 & 6,24 \\
$\mathbf{3}$ & Pemukiman & 88,05 & 24,95 \\
$\mathbf{4}$ & Pertanian Lahan Kering Bercampur Semak & 44,80 & 12,69 \\
$\mathbf{5}$ & Semak Belukar & 73,48 & 20,82 \\
\hline & Total & 352,89 & 100 \\
\hline
\end{tabular}

\section{Tutupan Lahan}

Kondisi tutupan lahan pada areal bufferzone sungai Apo yang menjadi lokasi penelitian tersaji pada Tabel 4. Tipe tutupan lahan hutan primer masih mendominasi areal penelitian khususnya pada areal sekitar hulu sungai yang berada di wilayah angkasa yakni sebesar $35 \%$ dari total areal bufferzone sungai Apo sedangkan hutan lahan kering sekunder memiliki luasan terkecil atau sebesar 6, 24\% dari total areal tersebut. Dari Tabel tutupan lahan juga dapat terlihat banyaknya aktifitas manusia pada areal bufferzone sungai Apo, hal ini dapat di lihat dari pemanfaatan lahan untuk menjadi pemukiman seluas 88,05 hektar atau sebesar $24,95 \%$ dan pertanian lahan kering bercampur semak (kebun yang secara kenampakan kurang terawatt) seluas 44,80 hektar atau sebesar $12,69 \%$ dari total areal bufferzone sungai Apo. Selain penutupan lahan yang sudah disebutkan diatas, pada table juga ditunjukan terdapat areal semak belukar seluas 73,48 hektar atau sebesar $20,82 \%$ dari total areal bufferzone sungai apo yang menjadi lokasi penelitian.

\section{Perubahan tutupan Lahan}

Kondisi tutupan lahan areal bufferzone sungai Apo sampai dengan tahun 2018 menunjukan masih terdapat $35,29 \%$ areal hutan primer dan $6,24 \%$ areal hutan sekunder, namun berdasarkan fungsi kawasan, sebagian besar atau $68,19 \%$ dari areal penelitian merupakan kawasan cagar Alam Cyclop yang seharusnya secara ekologi merupakan areal hutan karena suatu kawasan dapat ditunjuk menjadi kawasan cagar alam dengan pertimbangan bahwa kawasan tersebut memiliki kekhasan tumbuhan, satwa, dan ekosistemnya yang perlu dilindungi dan perkembangannya berlangsung secara alami sebagai penyangga kehidupan (Kartikasari et al, 2012).jika di lihat dari persentase kawasan berhutan yang terdapat pada areal penelitian sangat jauh di bawah angka persentase dari wilayah cagar alam pada areal tersebut seperti disajikan dalam Tabel 5.

Pada tahun 2000 sampai dengan 2009 areal hutan primer pada lokasi penelitian masih seluas 146 hektar dengan tingkat keanekaragaman yang tinggi (Uji, 2005) namun sampai dengan tahun 2018 areal hutan tersebut berkurang seluas 22,04 hektar sedangkan hutan lahan kering sekunder mengalami pengurangan dari tahun 2000 sampai 2009 seluas 44,80 hektar. Data tersebut menjawab asumsi bahwa penutupan lahan pada areal bufferzone sungai Apo mengalami perubahan seiring waktu berjalan, dan untuk melihat lebih rinci tentang bentuk perubahan tutupan lahan tersebut. 
Tabel 5 Matriks Perubahan Tutupan Lahan Areal Bufferzone Sungai Apo Periode Tahun 2000-2009

\begin{tabular}{|c|c|c|c|c|c|c|}
\hline $\begin{array}{l}\text { Tipe Tutupan } \\
\text { lahan }\end{array}$ & $\begin{array}{l}\text { Hutan } \\
\text { Lahan } \\
\text { Kering } \\
\text { Primer }\end{array}$ & $\begin{array}{c}\text { Hutan } \\
\text { Lahan } \\
\text { Kering } \\
\text { Sekunder }\end{array}$ & $\begin{array}{c}\text { Pem- } \\
\text { ukiman }\end{array}$ & $\begin{array}{c}\text { Pertanian } \\
\text { Lahan } \\
\text { Kering } \\
\text { Bercampur } \\
\text { Semak }\end{array}$ & $\begin{array}{c}\text { Semak } \\
\text { Belukar }\end{array}$ & $\begin{array}{c}\text { Grand } \\
\text { Total }\end{array}$ \\
\hline $\begin{array}{l}\text { Hutan lahan Kering } \\
\text { Primer }\end{array}$ & 124,52 & 22,04 & & & & 146,56 \\
\hline Pemukiman & & & 88,05 & & & 88,05 \\
\hline $\begin{array}{l}\text { Pertanian Lahan } \\
\text { Kering Bercampur } \\
\text { Semak }\end{array}$ & & & & 44,80 & & 44,80 \\
\hline $\begin{array}{l}\text { Semak/Belukar } \\
\text { Grand Total }\end{array}$ & 124,52 & 22,04 & 88,05 & 44,80 & $\begin{array}{l}73,48 \\
73,48\end{array}$ & $\begin{array}{c}73,48 \\
352,89\end{array}$ \\
\hline
\end{tabular}

Tabel matriks tutupan lahan di atas menunjukan pada tahun 2000 sampai dengan 2009 terjadi perubahan tutupan lahan, perubahan di periode tahun tersebut terjadi pada pada tipe tutupan hutan lahan kering sekunder. Hutan lahan kering sekunder cenderung mengalami pengurangan. Luasan hutan lahan kering sekunder pada tahun 2000 adalah sebesar 44,80 hektar dan seluruhnya terkonversi menjadi areal pertanian lahan kering bercampur semak di tahun 2009. Hal ini menunjukan besar aktifitas masyarakat dalam pembukaan lahan pada areal hutan sekunder sehingga menyebabkan hilangnya areal hutan lahan kering sekunder pada kurun waktu 9 tahun, sedangkan perubahan tutupan lahan yang terjadi pada lokasi penelitian di periode tahun 2009 sampai dengan tahun 2018 adalah penurunan kualitas hutan, hal ini ditunjukan dengan berubah atau berkurangnya areal dengan tipe tutupan hutan lahan kering primer menjadi hutan lahan kering sekunder seluas 22,04 hektar. Hutan lahan kering primer pada bufferzone sungai Apo yang sejak tahun 2000 adalah seluas 146,56 hektar di tahun 2018 tersisa 124, 52 hektar.

\section{Deforestasi dan Degradasi}

Sesuai dengan penurunan kualitas hutan lahan kering primer menjadi hutan lahan kering sekunder seluas 22,04 hektar di tahun 2009-2018 dan aktifitas yang mengakibatkan penghilangan hutan sekunder seluas 44,80 hektar di tahun 2000-2009 maka besar perubahan baik yang bersifat deforestasi maupun degradasi dari tahun 2000 sampai dengan tahun 2018 dengan demikian adalah seluas 66,84 hektar atau sebesar $18,94 \%$ dari total luasan areal penelitian yakni bufferzone sungai Apo.

Laju Deforestasi dan degradasi yang terjadi pada areal bufferzone sungai Apo keseluruhannya terjadi pada kawasan cagar alam yang secara administrasi berada pada wilayah kelurahan Angkasa Pura Distrik Jayapura Utara. Deforestasi dan degradasi disebabkan oleh aktifitas masyarakat yang melakukan perambahan terhadap hutan. Kondisi ini juga terjadi dibeberapa wilayah di Papua Barat seperti daerah Sorong (Arief et al 2019). Masyarakat melakukan penebangan pohon untuk dijadikan arang yang kemudian dijual kepada penadah dan kemudian lahan bekas penebangan dijadikan sebagai areal kebun yang ditanami nanas. Angka deforestasi dan degradasi yang terjadi pada areal bufferzone sungai Apo selama kurun waktu 18 
tahun terbilang cukup besar dengan ditunjukannya persentase degra-dasi dan deforestasi. Sehingga diperlukan langkah pengendalian yang sistematis pada areal yang teridentifikasi mengalami deforestasi dan degradasi juga pada areal lainnya yang menunjukan indikator sebagai lahan kritis mengingat areal bufeerzone sungai Apo sendiri mempuyai peran penting sebagai pengatur tata air yang akan dialirkan oleh sungai Apo, namun dalam pengambila kebijakan dalam menentukan langkah guna melakukan pengendalian terhadap areal ini perlu dilakukan perhitungan terhadap karakteristik lahan dan juga aturan pemerintah yang mendukung kebijajakan pengendalian tersebut.

\section{Rekomendasi Arahan Kesesuaian Pelaksanaan Rehabilitasi Hutan dan Lahan.}

Untuk mengambil langkah pengendalian dalam bentuk Rehabilitasi Hutan dan Lahan (RHL) terhadap kerusakan hutan pada areal bufferzone sungai Apo diperlukan perencanaan yang matang baik dari segi aturan maupun dari segi ekologi. Hal ini diperlukan mengingat tidak semua wilayah pada areal bufferzone dapat sesuai untuk melaksa-nakan kegiatan rehabilitasi hutan dan lahan sesuai dengan karakteristik lahan itu sendiri maupun secara penerapan aturan pemerintah yang mendukung kegiatan tersebut. Langkah awal yang perlu dilakukan dalam melaksanakan kegiatan RHL adalah memetakan wilayah mana saja pada areal bufferzone sungai Apo yang sesuai untuk melaksanakan kegiatan rehabilitasi hutan dan lahan sesuai kriteria lahan dan juga di dukung dengan kebijakan pemerintah dalam bentuk peraturan pemerintah pusat maupun pemerintah daerah.

Rekomendasi arahan kesesuaian lahan untuk melaksanakan kegiatan RHL pada areal bufferzone sungai Apo disusun berdasarkan Peraturan Mentri Kehutanan dan Lingkungan Hidup No 105 tahun 2018 tentang Rehabilitasi Hutan dan Lahan (RHL) yang lebih difokuskan pada Daerah Tangkapan Air (DTA), sungai, danau, dan waduk. Adapun parameter yang diperhatikan dalam langkah penentuan arahan kesesuaian lahan adalah peta lahan kritis nasional, fungsi kawasan, tutupan lahan, dan juga deforestasi dan degradasi pada wilayah dalam areal bufferzone sungai Apo.

Tabel 9 menunjukan bahwa berdasarkan karakteristik lahan maupun secara aturan dalam hal ini mengacu pada Peraturan Pemerintah (PERMEN), wilayah pada areal bufferzone sungai Apo tidak seluruhnya sesuai untuk melaksanakan kegiatan RHL. Terdapat tiga klasifikasi kesesuaian lahan pada areal tersebut, yaitu cukup sesuai, sesuai marginal. Data yang digunakan dalam melakukan skoring merupakan atribut tabel yang terkandung dalam data spasial.

Klasifikasi kesesuaian lahan pada masing-masing hamparan meliputi klasifikasi Cukup Sesuai yang artinya pada hamparan tersebut dapat dilaksanakan kegiatan rehabilitasi hutan dan lahan karena hampir tidak ada faktor pembatas baik secara aturan pemerintah maupun secara ekologi, jika dilihat pada peta hamparan yang yang masuk ke dalam kelas cukup sesuai sebagian besar merupakan areal hutan yang mengalami deforestasi dan degradasi. Klasifikasi Sesuai Marginal yang artinya pada hamparan tersebut dapat dilakukan kegiatan rehabilitasi hutan dan lahan tapi pada penerapannya akan mengalami hambatan atau batasan yang sangat berat untuk mempertahankan tingkat pengelolaan yang harus dilakukan. 
Tabel 9. Hasil skoring parameter untuk menghasilkan peta indikatif rekomendasi arahan kesesuaian lahan untuk melaksanakan kegiatan RH

\begin{tabular}{|c|c|c|c|c|c|c|c|c|c|c|c|c|}
\hline No & $\begin{array}{l}\text { Status } \\
\text { Kritis }\end{array}$ & Skor & $\begin{array}{l}\text { Fungsi } \\
\text { Kaw- } \\
\text { wasan }\end{array}$ & Skor & $\begin{array}{l}\text { Perubahan } \\
\text { Tutupan } \\
\text { Lahan }\end{array}$ & Skor & $\begin{array}{l}\text { Kondisi } \\
\text { tutupan lahan }\end{array}$ & Skor & $\begin{array}{l}\text { Total } \\
\text { Skor }\end{array}$ & $\begin{array}{l}\text { Klasifi- } \\
\text { kasi }\end{array}$ & $\begin{array}{l}\text { Nomor } \\
\text { Ham- } \\
\text { paran }\end{array}$ & $\begin{array}{l}\text { Luas } \\
\text { (Ha) }\end{array}$ \\
\hline 1 & $\begin{array}{l}\text { Agak } \\
\text { Kritis }\end{array}$ & 2 & APL & 2 & $\begin{array}{l}\text { Tidak } \\
\text { Berubah }\end{array}$ & 0 & Semak Belukar & 3 & 7 & $\begin{array}{l}\text { Cukup } \\
\text { Sesuai }\end{array}$ & 1 & 24,21 \\
\hline 2 & Kritis & 3 & $\begin{array}{l}\mathrm{KSA} \\
(\mathrm{Ca})\end{array}$ & 0 & $\begin{array}{l}\text { Defores- } \\
\text { tasi }\end{array}$ & 3 & $\begin{array}{l}\text { Pertanian la- } \\
\text { han kering } \\
\text { bercampur se- } \\
\text { mak }\end{array}$ & 2 & 8 & $\begin{array}{l}\text { Cukup } \\
\text { Sesuai }\end{array}$ & 2 & 44,66 \\
\hline 3 & Kritis & 3 & $\begin{array}{l}\mathrm{KSA} \\
(\mathrm{Ca})\end{array}$ & 0 & $\begin{array}{l}\text { Defores- } \\
\text { tasi }\end{array}$ & 3 & $\begin{array}{l}\text { Hutan lahan } \\
\text { kering } \\
\text { sekunder }\end{array}$ & 2 & 8 & $\begin{array}{l}\text { Cukup } \\
\text { Sesuai }\end{array}$ & 3 & 8,5 \\
\hline 4 & $\begin{array}{l}\text { Agak } \\
\text { Kritis }\end{array}$ & 2 & $\begin{array}{l}\mathrm{KSA} \\
(\mathrm{Ca})\end{array}$ & 0 & Degradasi & 3 & $\begin{array}{l}\text { Hutan lahan } \\
\text { kering } \\
\text { sekunder }\end{array}$ & 2 & 7 & $\begin{array}{l}\text { Cukup } \\
\text { Sesuai }\end{array}$ & 4 & 13,54 \\
\hline 5 & $\begin{array}{l}\text { Agak } \\
\text { Kritis }\end{array}$ & 2 & $\begin{array}{l}\mathrm{KSA} \\
(\mathrm{Ca})\end{array}$ & 0 & Degradasi & 3 & Semak belukar & 3 & 8 & $\begin{array}{l}\text { Cukup } \\
\text { Sesuai }\end{array}$ & 5 & 0,14 \\
\hline 6 & $\begin{array}{l}\text { Potensial } \\
\text { Kritis }\end{array}$ & 1 & APL & 2 & $\begin{array}{l}\text { Tidak } \\
\text { Berubah }\end{array}$ & 0 & Pemukiman & 1 & 4 & $\begin{array}{l}\text { Sesuai } \\
\text { Marginal }\end{array}$ & 1 & 80.72 \\
\hline 7 & $\begin{array}{l}\text { Agak } \\
\text { Kritis }\end{array}$ & 2 & $\begin{array}{l}\text { KSA } \\
(\mathrm{Ca})\end{array}$ & 0 & $\begin{array}{l}\text { Tidak } \\
\text { Berubah }\end{array}$ & 0 & Semak belukar & 3 & 5 & $\begin{array}{l}\text { Sesuai } \\
\text { Marginal }\end{array}$ & 2 & 48,59 \\
\hline 8 & Kritis & 3 & $\begin{array}{l}\text { KSA } \\
(\mathrm{Ca})\end{array}$ & 0 & $\begin{array}{l}\text { Tidak } \\
\text { Berubah }\end{array}$ & 0 & Semak belukar & 3 & 6 & $\begin{array}{l}\text { Sesuai } \\
\text { Marginal }\end{array}$ & 3 & 0,67 \\
\hline 9 & $\begin{array}{l}\text { Tidak } \\
\text { Kritis }\end{array}$ & 0 & $\begin{array}{l}\text { KSA } \\
(\mathrm{Ca})\end{array}$ & 0 & $\begin{array}{l}\text { Tidak } \\
\text { Berubah }\end{array}$ & 0 & Pemukiman & 1 & & $\begin{array}{l}\text { Tidak } \\
\text { Sesuai }\end{array}$ & 1 & 7,33 \\
\hline 10 & $\begin{array}{l}\text { Agak } \\
\text { Kritis }\end{array}$ & 2 & $\begin{array}{l}\text { KSA } \\
(\mathrm{Ca})\end{array}$ & 0 & $\begin{array}{l}\text { Tidak } \\
\text { Berubah }\end{array}$ & 0 & $\begin{array}{l}\text { Hutan lahan } \\
\text { kering primer }\end{array}$ & 0 & & $\begin{array}{l}\text { Tidak } \\
\text { Sesuai }\end{array}$ & 2 & 112,99 \\
\hline 11 & $\begin{array}{l}\text { Potensial } \\
\text { Kritis }\end{array}$ & 1 & $\begin{array}{l}\text { KSA } \\
(\mathrm{Ca})\end{array}$ & 0 & $\begin{array}{l}\text { Tidak } \\
\text { Berubah }\end{array}$ & 0 & $\begin{array}{l}\text { Hutan lahan } \\
\text { kering primer }\end{array}$ & 0 & & $\begin{array}{l}\text { Tidak } \\
\text { Sesuai }\end{array}$ & 3 & 8,54 \\
\hline 12 & $\begin{array}{l}\text { Tidak } \\
\text { Kritis }\end{array}$ & 0 & $\begin{array}{l}\text { KSA } \\
(\mathrm{Ca})\end{array}$ & 0 & $\begin{array}{l}\text { Tidak } \\
\text { Berubah }\end{array}$ & 0 & $\begin{array}{l}\text { Hutan lahan } \\
\text { kering primer }\end{array}$ & 0 & & $\begin{array}{l}\text { Tidak } \\
\text { Sesuai }\end{array}$ & 4 & 2,99 \\
\hline & & & & & & & & & & Luas total & & 352,89 \\
\hline
\end{tabular}

Areal pembangunan baik yang bersifat perumahan, perto-koan, maupun aset bangunan pemerintah pada hamparan ini menjadi faktor pembatas yang cukup besar. Klasifikasi Tidak Sesuai yang artinya tidak diperlukan pelaksanaan kegiatan RHL pada hamparan tersebut, berdasarkan hasil skoring dapat dilihat bahwa hamparan yang masuk pada klasifikasi ini sebagian besar tutupan lahannya adalah hutan lahan kering primer sehingga tidak diperlukan kegiatan rehabilitasi pada hamparan tersebut. Hasil penelitian ini menunjukan bahwa lahan yang direkomendasikan cukup sesuai untuk melaksanakan kegiatan RHL pada areal bufferzone sungai Apo hanya seluas 91,05 hektar atau sebesar 25,80\% dari luas areal bufferzone sungai Apo.

\section{KESIMPULAN}

Hasil penelitian ini menunjukkan bahwa areal bufferzone sepanjang 500 meter ke kiri dan kanan dari sungai Apo, memiliki karakteristik tipe tutupan lahan hutan lahan kering primer, hutan lahan kering sekunder, pertanian lahan kering bercampur semak, semak belukar, pemukiman, tipe tanah litosol, dengan ketinggian tempat yang berkisar dari $0 \mathrm{~m}$ dpl - 690m dpl. Kelerengan pada areal bufferzone sangat berfariasi mulai dari datar sampai sangat curam.

Laju deforestasi dan degradasi pada areal penelitian adalah sebesar 18,94\% terhitung tahun 2000 sampai dengan tahun 2018. Kelas kesesuaian lahan tertinggi pada peta rekomendasi arahan kesesuaian lahan untuk melaksa-nakan RHL adalah cukup sesuai dengan luasan hamparan sebesar 91,05 hektar. 
DAFTAR PUSTAKA

Arief SM, Siburian R H, Wahyudi. 2019. Tingkat Kerentanan Banjir Kota Sorong Papua Barat. Median Jurnal Vol 11. No. 2. Doi http://doi.org/10.33506/md.v11i2. 456

Departemen Kehutanan, 1999. UndangUndang Nomor 41 Tahun 1999. Pemerintah Republik Indonesia. Jakarta

Dinas Pekerjaan Umum Bidang Cipta Karya.2016. Profil Kota Jayapura.Pemerintah Kota Jayapura

FAO (Food and Agriculture Organization. 1976. A Framework for Land Evaluation. FAO Soil Bulletin 52.

Soil Resources Management and Conservation Service Land and Water Development Division.

Kartikasari SN, Marshall A.J, Beehler B.M. 2012. Ekologi Papua. Yayasan Pustaka Obor Indonesia, Jakarta.

Peraturan Menteri Lingkungan Hidup dan Kehutanan.2018. Nomor P.105/MENLHK/SETJEN/

KUM.1/12/2018. Tata Cara Pelaksanaan, Kegiatan Pendukung, Pemberiaan Insentif, Serta Pengendalian Kegiatan Rehabilitasi Hutan Dan Lahan. Pemerintah Republik Indonesia.Jakarta.
Surat Keputusan Kementrian Kehutanan tanggal 27 Desember 2012 Nomor:SK.782/Menhut-II/2012 Perubahan Atas Keputusan Menteri Kehutanan dan Perkebunan Nomor 891/KPTS-II/1999 Tentang Penunjukan Kawasan Hutan di Wilayah Provinsi Daerah Tingkat I Irian Jaya Seluas \pm 42.224 .840 Ha.

Tanati A. Siburian R H, Murdjoko A. 2020. Persepsi masyarakat terhadap pengelolaan lingkungan di kelurahan Amban Kabupaten Manokwari. Median Journal Volume 12. Nomor 3. Doi http://doi.org/10.33506/md.v12i3. 761.

Uji T. 2005. Keanekaragaman dan Potensi Flora di Cagar Alam Pegunungan Cyclops, Papua. Jurnal Teknologi Lingkungan. Vol 6, No. 3.

Wibowo E. J, Wahyudi, Siburian R H. 2020. Analisis ketersediaan dan kebutuhan ruang terbuka hijau Publik pada Kawasan Perkotaan Bintuni di Wilayah Manimeri. Median Journal Volume 12 Nomor 3. Doi: https://doi.org/10.33506/md. v12i3.1100

Yunianta.A, 2016. Analisa Sistem Pengendalian Banjir Daerah Aliran Sungai (DAS) APO Kota Jayapura Propinsi Papua. 